\title{
LIVROS DIDÁTICOS DE HISTÓRIA DO BRASIL PARA O ENSINO SECUNDÁRIO (1889-1950): PROCEDIMENTOS DE LOCALIZAÇÃO, SELEÇÃO E ACESSO
}

\author{
Textbooks of history of brazil to high school (1889-1950): localization, selection \\ and access procedures
}

\section{Manuales escolares de história de brasil para la enseñanza secundária: procedimientos de localización, selectión y acceso}

Kênia Hilda Moreira ${ }^{1}$

\begin{abstract}
Resumo
Objetiva-se apresentar os procedimentos metodológicos utilizados para definir os livros didáticos de História do Brasil para o ensino secundário mais usados no contexto escolar, desde a Proclamação da República (1889) até 1950 no Brasil. O artigo evidencia os procedimentos metodológicos para localização e seleção, na primeira parte e em seguida apresenta o corpus documental selecionado (obras e autores).
\end{abstract}

PALAVRAS-CHAVE: História da Educação. Procedimentos metodológicos. Livros didáticos.

\begin{abstract}
The purpose of this paper is to present the methodological procedures used to define the textbooks of History of Brazil to secondary education most used in the school context, from the Proclamation of the Republic (1889) to 1950, in Brazil. The article highlights the methodological procedures for localization and selection, in the first part and then presents the selected documentary corpus (textbooks and authors).
\end{abstract}

KEYWORDS: History of Education. Methodological procedures. Textbooks.

\section{Resumen}

Se objetiva presentar los procedimientos metodológicos utilizados para definir los manuales escolares de Historia de Brasil para la enseñanza secundaria más usados en el contexto escolar, desde la Proclamación de la República (1889) hasta 1950 en Brasil. El artículo evidencia los procedimientos metodológicos de localización y selección, en la primera parte y luego presenta el corpus documental seleccionado (obras y autores).

PALABRAS ClAVE: Historia de la Educación. Procedimientos metodológicos. Manuales.

\section{INTRODUÇÃO}

Considerando que algumas das dificuldades em se ter o livro didático como fonte/objeto de estudo e investigação refere-se à localização, recuperação e catalogação de exemplares, principalmente quando dos títulos "antigos", como assinalam Choppin (2017), Collados Cardona (2008) e Tiana Ferrer (2017), apresentamos os

\footnotetext{
${ }^{1}$ Doutora em Educação Escolar. Professora no Programa de Pós-Graduação em Educação e na Faculdade de Educação da Universidade Federal da Grande Dourados. Rua João Rosa Gois, 1761, Vila Progresso, Dourados. Fone (67) 34102121. E-mail: keniamoreira@ufgd.edu.br
} 
procedimentos metodológicos utilizados para definir os livros didáticos de História do Brasil para o ensino secundário mais usados no contexto escolar, desde a Proclamação da República no Brasil até $1950^{1}$.

De modo geral, o livro didático utilizado como objeto de consumo rápido não suscitou interesse em conservá-lo. Choppin (2017) argumenta que a pouca atenção dada a esse material até recentemente não surpreende, pois vários fatores contribuíram para manter o desinteresse. Entre eles, o fato de que os livros didáticos formam parte do cotidiano, parecem atemporais, gozam de familiaridade tal que lhes subtrai valor, sem contar a produção abundante, tornando-se um produto pouco valorizado.

Segundo fator, os livros didáticos são perecíveis, estão à mercê das mudanças dos programas curriculares e a partir da década de 1960, a evolução econômica, social, técnica e cultural somadas ao desenvolvimento das inovações pedagógicas, com a massificação do ensino e o recurso das novas tecnologias, favoreceu a renovação da produção, o aumento e a diversificação da oferta editorial. Terceiro motivo: a trivialidade, a abundância e a ampla difusão da produção escolar não convencem bibliotecários da necessidade de conservação desse material, que só perde para os jornais no que diz respeito ao consumo de papel. Até a década de 1960 não havia bibliografias nem catálogos dedicados especificamente à literatura escolar (CHOPPIN, 2017).

Tiana Ferrer (2017), por usa vez, lembra que, apesar da longa história do livro didático no campo educacional, este material foi concebido como eminentemente instrumental e não foram produzidos esforços sistemáticos de conservação. Para o autor, alguns títulos com várias edições e exemplares distribuídos aos milhões, deixaram poucos vestígios. Considerados geralmente como objetos de consumo, são facilmente descartados. Collados Cardona (2008) expõe que "o trabalho com estes materiais frequentemente dispersos, e fisicamente muito vulneráveis, faz com que a simples localização e catalogação de exemplares consumam considerável energia nos trabalhos de campo" (COLLADOS CARDONA, 2008, p. 325).

Com base nesses argumentos, justificamos a importância de uma pesquisa com livros didáticos em perspectiva histórica atentar-se em evidenciar com minúcias seus procedimentos metodológicos, podendo colaborar com pesquisas futuras.

Esse é o intuito do presente artigo, que tem como corpus documental os livros didáticos de História do Brasil para o ensino secundário, desde a proclamação da República no Brasil, até findada a metade do século, quando termina a vigência da Lei Orgânica do Ensino secundário, de 1942. Nas décadas iniciais da República, o ensino secundário vigente resultou de um processo de institucionalização marcado pelo embate com o sistema de exames parcelados. Como lembra Haidar (2008, p. 12), para ingressar nos cursos superiores bastava a aprovação nos exames preparatórios. Com o Ministério da Educação e Saúde Pública, as reformas Francisco Campos e Gustavo Capanema, introduziram mudanças significativas no ensino secundário, instituindo um sistema educacional de nível nacional, ao contrário dos anos iniciais da República, onde os esforços foram direcionados para o ensino primário.

\footnotetext{
${ }^{1} \mathrm{O}$ artigo foi escrito a partir do capítulo de metodologia da tese de doutorado de Moreira (2011). O recorte temporal está delimitado entre 1889, quando se inicia o governo republicano, e 1950, último ano de vigência da Lei Orgânica do Ensino secundário, de 1942, e dos respectivos programas de ensino elaborados em âmbito federal pelo Ministério da Educação e Saúde Pública.
} 
$\mathrm{O}$ artigo divide-se em duas partes, na primeira evidenciamos os procedimentos metodológicos para localização e seleção e na segunda parte apresentamos o corpus documental selecionado.

\section{Localização e seleção do corpus documental}

Como procedimento de localização das obras didáticas de ensino secundário mais utilizadas para a disciplina História do Brasil (entre 1889 e 1950), primeiramente levantamos quais seriam nossas fontes de busca, para em seguida, localizar as referidas obras.

Para sistematizar a localização de livros didáticos, Delgado (1983) propõe o estudo dos livros de contabilidade das editoras, a publicidade em jornais e revistas, os livros de visita de inspeção escolar e as listas das bibliotecas escolares e públicas. Esteban Mateo (1997), ao apresentar os catálogos de livraria e material de ensino como fonte iconográfica e literário-escolar, lembra que os catálogos constituem fonte de informação, porém não permitem a investigação em si mesmo, ainda que irremediavelmente conduza a ela. No entanto, não tivemos acesso a tais fontes, dentro do recorte temporal estabelecido por nós, o que nos fez descartar essa alternativa. Para Choppin (2004), além dos catálogos, que dificilmente são conservados, as listas de livros didáticos anteriores a 1970 podem ser localizadas consultando-se o rol de títulos aprovados pelas instâncias governamentais ou em trabalhos acadêmicos ou em preocupações de bibliotecários às voltas com a recuperação de fundos gerais e negligenciados de acervos. Nas fontes propostas por Choppin tivemos mais êxito, como apresentamos a seguir.

\section{Fontes para a localização do corpus documental}

Como fontes para a localização dos livros didáticos de História do Brasil para o ensino secundário no período de 1889-1950 utilizamos:

- A lista de títulos de História do Brasil indicados pelos programas de ensino do Colégio Pedro II, 1889 e 1930, disponíveis em Vechia e Lorenz (1998).

(A obra de Ariclê Vechia e Karl Lorenz é uma compilação dos "Programas de ensino da escola secundária brasileira: 1850-1951", publicado pela Editora do Autor, em 1998. Os autores informam que não localizaram os programas de ensino de 1899 e de 1901).

- A lista de livros didáticos de História do Brasil para o curso secundário, em acordo com os programas de ensino de 1931 a 1949, disponível em Holanda (1957).

(Guy de Holanda publicou em 1957, pelo Instituto Nacional de Estudos Pedagógicos (INEP) e pelo Centro Brasileiro de Pesquisas Educacionais (CBPE), a obra "Um quarto de século de programas e compêndios de História para o ensino secundário. 1931-1956", contendo, ao final, um apêndice dos livros didáticos de História que foram examinados por ele, de acordo com os programas curriculares de 1931, 1940, 1942, 1945,1949 e 1951). 
- Os livros didáticos de História do Brasil, publicados entre 1889 e 1950 e que foram corpus de pesquisas acadêmicas, dissertações e tese, conforme Moreira e Silva (2011).

(A obra de Moreira e Silva, intitulada "Um inventário: o livro didático de história em pesquisas (1980 a 2005)", publicada pela editora da Unesp, em 2011, levanta os livros didáticos de História utilizados como fontes das pesquisas realizadas no Brasil entre 1980 e 2005, constante no quadro 6, nas páginas 137-138).

- Os didáticos de História do Brasil para o ensino secundário, publicados entre 1889 a 1950, constantes na biblioteca de Livros Escolares (LIVRES), presente na Faculdade de Educação da Universidade de São Paulo, disponível em seu Banco de Dados.

(A Biblioteca LIVRES, oferece um Banco de Dados virtual ${ }^{2}$ que disponibiliza a relação de seu acervo composto de obras didáticas de diversas disciplinas escolares entre 1810 a 2005, além do acervo de outras Bibliotecas).

\section{Primeira localização do corpus documental}

A partir da análise rigorosa das fontes apresentadas acima (detalhada no Apêndice A), localizamos:

- Seis autores/obras indicados nos programas do Colégio Pedro II entre 1892 a 1929, a saber: 1898);

- História do Brasil, de Luiz de Queiroz Mattoso Maia (Programas de 1895 e

- Escragnolle Dória e João Ribeiro, sem referências às obras (Programa de 1915);

- História do Brasil, de Pedro do Couto, e História do Brasil, de Veiga Cabral (Programa de 1926);

- Quadros de História Pátria, de Basílio de Magalhães e Max Fleiuss, e História do Brasil, de Otelo Reis (Programa de 1929).

- 25 títulos publicados de "acordo com os programas para o ensino secundário" de 1931 e 1949 conforme dados constantes em Holanda (1957):

- 3 títulos no Programa de 1940: História do Brasil para a $4^{a}$ série fundamental, História do Brasil para a $5^{\text {a }}$ série fundamental, de Alfredo Gomes, e História do Brasil, de Basílio de Magalhães;

- 18 títulos no Programa de $1942^{3}$ : História do Brasil, $3^{\mathrm{a}}$ série, curso ginasial, de Antônio José Borges Hermida, História do Brasil, (Resumo didático), de Roberto

\footnotetext{
${ }^{2}$ A consulta, simples ou avançada, ao Banco de Dados LIVRES pode ser feita buscando por: Disciplina; Autor; Editora; Título; ou Período. O sistema de busca permite a consulta ao acervo da Biblioteca de Livros Didáticos da FE-USP (LIVRES). Disponível em: 〈http://paje.fe.usp.br/estrutura/livres/>. Acesso em: 12 nov. 2009.

${ }^{3}$ Existe uma variação na data desse programa. Ora se considera o ano de 1942, ano da Reforma de Ensino em acordo com a Lei Orgânica do Ensino Secundário; ora 1943, ano de publicação dos programas para a disciplina História do Brasil para as $3^{\mathrm{a}}$ e $4^{\mathrm{a}}$ séries do curso ginasial. Em 1945 publicou-se o programa de
} 
Macedo, História do Brasil, $3^{\text {a }}$ série, de Basílio de Magalhães, História do Brasil, para a $3^{\text {a }}$ série ginasial, de Ary da Matta, História do Brasil, $3^{\mathrm{a}}$ série, de Orestes Rosália, História do Brasil, $3^{\text {a }}$ série do curso ginasial, e História do Brasil, $4^{\mathrm{a}}$ série, de Jonathas Serrano, História do Brasil, $4^{\text {a }}$ série do curso secundário, Mário Sette, História do Brasil para a $3^{\mathrm{a}}$ série ginasial, e História do Brasil para a $4^{\mathrm{a}}$ série ginasial, de Joaquim Silva, História do Brasil para a $4^{\mathrm{a}}$ série ginasial, de Alcindo Muniz de Souza, História do Brasil ( $3^{a}$ série), de Octávio Tarquínio de Souza e Sérgio Buarque de Hollanda, História do Brasil Primeiro Volume e História do Brasil Segundo Volume, de Artur Gaspar Viana, História do Brasil Colonial para a $3^{\mathrm{a}}$ série ginasial e História do Brasil para a $4^{\mathrm{a}}$ série, de Hélio Vianna, e História do Brasil $3^{a}$ série e História do Brasil $4^{a}$ série, de João Pereira Vitória;

- 2 títulos no Programa de 1945: História do Brasil, adaptada ao Curso de Colégio, de Vicente Tapajós, e História do Brasil, $3^{\circ}$ ano colegial, de Hélio Vianna;

- 2 títulos no Programa de 1949: História do Brasil, $4^{\text {a }}$ série ginasial, de Alcindo Muniz de Souza, História do Brasil, $4^{a}$ série ginasial, de Joaquim Silva (Programa de 1949).

- 42 ocorrências no acervo da biblioteca de livros escolares, pelo Banco de Dados LIVRES, com 37 autores.

- Seis autores em Moreira e Silva (2011): História do Brasil curso superior, de João Ribeiro, Lições de História do Brasil, de Joaquim Manuel de Macedo, História do Brasil, de Basílio de Magalhães, História do Brasil, de Joaquim Silva, Epítome de História do Brasil, de Jonathas Serrano e História do Brasil para o ensino secundário, de Rocha Pombo.

Alguns autores e títulos se repetem entre as fontes. Ou seja, a soma dos títulos encontrados, 77, não corresponde ao total de títulos localizados, como pode ser evidenciado no quadro que forma o Apêndice A, que evidencia 50 autores, que em alguns momentos escreveram em coautoria e três colaboradores. Deve-se considerar também que os autores escrevem obras didáticas para diferentes séries, fracionando o conteúdo de História da Brasil, ao cumprir com o programa curricular em vigor.

\section{Critérios de seleção dos autores e títulos}

Dada a impossibilidade de acessar todas as obras localizadas pelos nossos procedimentos de busca, optamos por selecionar as obras com maior recorrência, indicando terem sido as obras mais utilizadas no contexto escolar dentro do nosso recorte temporal. um título:

Ossenbach Sauter (2007) menciona quatro critérios para análise da difusão de edição.

- A vida editorial do livro, ou seja, tempo decorrido entre primeira e última

- Número de edição, com cuidado, pois esse índice geralmente é dado comercial.

- Número de edições conservadas em bibliotecas. 
- Presença desses livros didáticos em "sebos". 4

O primeiro critério é difícil de ser estabelecido tendo em vista o caráter instrumental do livro didático. Todavia, no período aqui investigado, os exemplares tendiam a ser utilizados por mais de uma geração, o que de certo modo, facilita o mapeamento das edições, além da existência de investigações sobre os títulos considerados.

O segundo critério não é muito confiável, pelos motivos expostos pela autora. Porém, consideramos esse critério levando em conta as edições localizadas nas quatro fontes disponíveis em especial na biblioteca LIVRES. Esta fonte permite localizar as sucessivas edições de título, o que nos remete ao terceiro critério: o número de edições conservadas em biblioteca.

O quarto critério foi considerado quando passamos para a etapa de aquisição de exemplares em "sebos" virtuais.

Como expõe Ossenbach Sauter, selecionar títulos didáticos mais utilizados implica na escolha metodológica do ponto de vista econômico ou tradicional, em outras palavras, significa escolher os títulos mais vendidos, ou os utilizados em longo período de anos. $\mathrm{O}$ aspecto econômico é um fator a ser considerado. O preço de um livro pode ser a causa de sua rápida ou lenta difusão. Porém, nem sempre o número de exemplares vendidos avalia sua qualidade e aceitação, sobretudo quando se trata de uma instituição, seja religiosa ou de outra natureza, que o impõe como obrigatório.

A escolha metodológica pelos livros didáticos mais difundidos nos beneficia ou pelo menos não nos prejudica, uma vez que pretendemos analisar "visões e revisões" de determinados temas.

Entre os critérios de seleção para identificar os livros mais usados recorremos aos seguintes:

- recorrência de títulos entre as fontes disponíveis;

- longevidade dos títulos;

- autores com maior quantidade de títulos; e

- títulos mais investigados em estudos acadêmicos.

Os três primeiros critérios puderam ser analisados a partir da criação do quadro que forma o Apêndice A. No tocante ao quarto critério utilizamos levantamentos existentes em dissertações de mestrado e teses de doutorado produzidas entre 1980 e 2005 (MOREIRA; SILVA, 2011).

\section{Aplicação dos critérios de seleção}

Ao analisar os dados do Apêndice A relativos ao levantamento dos livros didáticos de História do Brasil nas fontes investigadas, nota-se a existência de autores com grande número de títulos. Entre os autores com cinco títulos ou mais estão:

\footnotetext{
${ }^{4}$ Ossenbach Sauter em palestra no Simpósio Internacional de Livro Didático, na Faculdade de Educação da Universidade de São Paulo - 2007.
} 
- Ary da Matta, 6; Basílio de Magalhães, 9; Joaquim Silva, 8; Jonathas Serrano, 6; Rafael Maria de Galanti, 5.

Entre os títulos recorrentes:

- História do Brasil de Basílio de Magalhães, Lições de História do Brasil de Luiz de Queiroz Mattoso Maia, História do Brasil de Mário da Veiga Cabral e Pontos de História do Brasil de Pedro do Couto.

Entre os títulos com número significativo de edições:

- Lições de História do Brasil de Joaquim Manuel de Macedo. (1. ed. 1861, 9. ed. 1922, total 11 edições). (Como afirmam as pesquisas de Gasparello, 2002, Melo, 1997, Bittencourt, 1993).

- História do Brasil curso superior de João Ribeiro. (1. ed. 1900, 19. ed. 1966 ampliada por Joaquim Ribeiro).

- História do Brasil: para o ensino secundário de Rocha Pombo. (1. ed. 1918, 19. ed. década de 1930).

- História do Brasil de Vicente Tapajós. (1. ed. 1944, 15. ed. 1969).

- História do Brasil: para o $4^{\circ}$ ano ginasial. (15. ed. 1946, 30. ed. 1952); História do Brasil: para o $3^{\circ}$ ano ginasial (31. ed. 1950, 40. ed. 1952); História do Brasil: para a $1^{a}$ série ginasial (20. e 21. edições em 1953, 40. ed. 1955), os três títulos de Joaquim Silva. Não localizamos as datas das primeiras edições.

Entre os títulos e autores mais investigados, conforme Moreira e Silva (2011) encontram-se:

- João Ribeiro ${ }^{5}$, Rocha Pombo $^{6}$, Basílio de Magalhães ${ }^{7}$, Joaquim Silva ${ }^{8}$, Joaquim Manuel de Macedo ${ }^{9}$, e Jonathas Serrano ${ }^{10}$.

A partir da aplicação dos critérios selecionados, 12 autores são mencionados: Ary da Matta, Basílio de Magalhães, Joaquim Silva, Jonathas Serrano, Rafael Maria de Galanti, Luiz de Queiroz Matosso Maia, Mario da Veiga Cabral, Pedro do Couto, Joaquim Manuel de Macedo, João Ribeiro, Rocha Pombo e Vicente Tapajós.

\section{Composição do corpus documental}

Para compor o corpus documental selecionamos autores e não títulos e após a seleção escolhemos um título por autor. Tal critério pode ser justificado, conforme

\footnotetext{
5 Analisado por Resnik (1992), Bittencourt (1993), Melo (1997), Gasparello (2002), Bueno (2003), Ribeiro (2004), Rodrigues (2004) e Caldas (2005). Além de Hansen (2000) que não compõe o mapeamento, mas analisa o autor.

${ }^{6}$ Investigado por Thompson (1989), Bittencourt (1993), Bueno (2003), Ribeiro (2004), Rodrigues (2004), Caldas (2005) e Silva Filho (2005). Além de Queluz (1998) e Lucchesi (2004), dentre outros.

${ }^{7}$ Por Thompson (1989), Resnik (1992), Bittencourt (1993), Gasparello (2002) e Rodrigues (2004). Além de Pinto (2000).

${ }^{8}$ Por Thompson (1989), Resnik (1992), Bueno (2003), Ribeiro (2004) e Caldas (2005).

${ }^{9}$ Por Bittencourt (1993), Melo (1997), Gasparello (2002) e Ribeiro (2004). Além de Mattos (2000), que dedica sua pesquisa a este autor.

${ }^{10}$ Por Resnik (1992), Bittencourt (1993) e Demori (2000), além de Vidal (2005), Zanatta (2005) e Oliveira (2006).
} 
Moreira e Silva (2011), ao referirem-se a autoria de livros didáticos no Brasil e afirmarem que a "democratização do ensino" na década de 1960 alterou as características dos autores de didáticos até então carregados de prestígio. Ou seja, no período delimitado para investigação a maioria dos autores eram mais renomados do que os títulos em si.

Feitas essas observações, retomamos aos 12 autores após a aplicação dos critérios de seleção. Dentre eles, dois autores aparecem em três critérios de seleção: Basílio de Magalhães e Joaquim Silva. Quatro autores em dois critérios: Joaquim Manuel de Macedo, João Ribeiro, Jonathas Serrano e Rocha Pombo.

- Basílio de Magalhães publica títulos didáticos de 1895 a 1958.

- Joaquim Silva escreve e publica títulos didáticos entre 1933 a 1971, pelo que temos notícia.

- Joaquim Manuel de Macedo escreve e publica títulos didáticos em 1861-1863, os títulos foram reeditados até 1928 .

- João Ribeiro escreve e publica títulos didáticos em 1900. Há dados de reedições até 1966.

- Jonathas Serrano escreve e publica a partir de 1912. Há dados de reedições até 1968.

- Rocha Pombo escreve e publica títulos didáticos na República, todavia, notese, sua História do Brasil é iniciada em 1890. Há dados de reedições até 1968.

Esses seis autores perpassam as conjunturas presentes na periodização eleita para a realização dos nossos estudos e pesquisas (1889-1950). Um autor inicia sua produção no Segundo Império: Joaquim Manuel de Macedo. Três autores na Primeira República: Basílio de Magalhães, João Ribeiro e Rocha Pombo; dois na Segunda República: Joaquim Silva e Jonathas Serrano.

Com base nessas observações elegemos os seis autores para compor o corpus documental: Basílio de Magalhães, João Ribeiro, Joaquim Manual de Macedo, Joaquim Silva, Jonathas Serrano e José Francisco da Rocha Pombo.

Considerando a (s) série (s) em que estava situada a disciplina História do Brasil, de acordo com os programas de ensino e a disponibilidade e acesso ${ }^{11}$ aos exemplares dos títulos selecionamos:

- Lições de História do Brasil de Joaquim Manuel de Macedo (Rio de Janeiro: Editora Garnier em 1922) [1. ed. 1861]. Título indicado nos programas do Colégio Pedro II até 1882. Reeditado até 1928.

- História do Brasil curso superior de João Ribeiro. (Rio de Janeiro: Francisco Alves: 1928) [1. ed. 1900]. Indicado nos programas do Colégio Pedro II até 1915.

- História do Brasil para o ensino secundário de Rocha Pombo. (São Paulo: Editora Melhoramentos, 1925?). [1. ed. 1918]. Reeditado até 1967.

- Epítome de História do Brasil de Jonathas Serrano. (Rio de Janeiro: Editora F. Briguiet \& Cia, 1941) [1. ed. 1933]. Título lançado após a reforma Francisco Campos e serviu de referência para a disciplina História da América e do Brasil.

\footnotetext{
${ }^{11}$ Tivemos acesso a todas as obras selecionadas pelo sebo virtual.
} 
- História do Brasil de Basílio de Magalhães. Dois volumes - $5^{a}$ série ginasial e $2^{a}$ série dos cursos clássico e científico. (Rio de Janeiro: Francisco Alves, 1942, 1958). De acordo com o programa de ensino de 1940.

- História do Brasil de Joaquim Silva. Dois volumes - $3^{\mathrm{a}}$ e $4^{\mathrm{a}}$ série ginasial. (São Paulo: Editora Companhia Nacional, 1943, 1944). De acordo com o programa de 1943.

\section{Apresentação do corpus selecionado}

A seguir apresentamos individualmente cada obra e seu respectivo autor. A apresentação dos autores, como parte da exposição do corpus selecionado, leva em consideração a observação de Choppin (1980), ao afirmar ser relevante conhecer a personalidade e os centros de interesses dos autores dos manuais, bem como suas atividades profissionais, tendências políticas e religiosas, detalhando as complexas relações que emergem do processo de produção dos livros didáticos.

\section{Lições de História do Brasil, de Joaquim Manuel de Macedo}

O primeiro livro didático de História do Brasil a ter larga aceitação foi Lições de História do Brasil, de Joaquim Manuel de Macedo ${ }^{12}$. Editada pela livraria Garnier em dois volumes, em 1861 e 1863 , para o $4^{\circ}$ e $7^{\circ}$ ano ${ }^{13}$.

O livro se manteve na Primeira República, sendo revisto e atualizado por Olavo Bilac até 1905, e posteriormente por Rocha Pombo. Foi indicado no Ginásio de São Paulo após a reformulação do programa de 1928 (BITTENCOURT, 1990).

Joaquim Manuel de Macedo (1820-1883) formou-se em medicina, mas não a exerceu. Foi membro do Instituto Histórico e Geográfico Brasileiro (IHGB), ocupou os cargos de primeiro secretário, orador oficial e presidente. Seu principal meio de vida foi o magistério, iniciado em 1843 e no Colégio Pedro II em 1849.

Escreveu Lições de corografia brasileira (Editora Garnier, 1873), posteriormente traduzido para o francês. Mulheres célebres (Editora Garnier, 1878), destinado às escolas femininas e romances como A moreninha.

Lições de História do Brasil foi escrito para alunos do Colégio Pedro II de acordo com o programa de ensino para a disciplina, fato que garantiu ao livro a concessão de benefícios, como o apoio à impressão e prêmios oficiais. O prestígio por servir ao Colégio Pedro II, além de ser o autor professor na instituição e sócio do IHGB, geraram as condições de sucesso do livro.

O título teve 11 edições com seis mil exemplares em cada edição, o que o tornou o autor didático mais lido no século XIX. A aceitação de Lições deve-se também ao pioneirismo na explicitação do método didático recomendado aos professores. No

\footnotetext{
12 Joaquim Manuel de Macedo inaugura o segundo momento dos livros didáticos de História no Brasil de acordo com Bittencourt (1993) e Gasparello (2002). O momento inicial compreende Resumo de História do Brasil de Bellegarde (Laemmert, 1831) e Compêndio de História do Brasil de José Inácio de Abreu e Lima (Laemmert em 1843).

${ }^{13} \mathrm{O}$ segundo volume foi escrito para "estudantes mais habilitados" tendo em vista a alocação da disciplina no estágio final do curso secundário. Cf. Melo (1997), Mattos (2000) e Gasparello (2002).
} 
prefácio da primeira edição o autor explica que "uma obra escrita para servir ao estudo de meninos não deve ser longa, todavia este só avulta pelas explicações, pelos quadros sinóticos e pelas perguntas que seguem às lições" espaço onde "se encontram as bases principais do método" adotado pelo autor.

O exemplar aqui selecionado pertence à edição de 1907, "décima edição completada de $1823^{14}$ a 1905 por Olavo Bilac", Garnier, 513 páginas e 62 lições, as sete últimas são "índices cronológicos". Contém quadro sinóptico e perguntas ao final das lições.

\section{História do Brasil curso superior, de João Ribeiro}

Editado pela Livraria Cruz Coutinho, de propriedade de Jacinto Ribeiro dos Santos, 1900, História do Brasil de João Ribeiro "continha a matéria essencial do estudo feito nas escolas primárias e secundárias". O autor aceitou o conselho de dividir o livro em "duas edições separadas, uma destinada a infância e outra aos cursos superiores" (RIBEIRO, 1900, p. VI), que correspondem às classes de Ginásio e Escola Normal. Em 1900 o título para as escolas primárias foi reeditado pela Editora Francisco Alves ${ }^{15}$.

Acessamos o exemplar para o ensino secundário: Curso Superior, $11^{\mathrm{a}}$ edição, "segundo os programas do Colégio Pedro II", "refundida e inteiramente revista e melhorada", Editora Francisco Alves, 1928.

João Batista Ribeiro de Andrade Fernandes (1860-1934), conhecido como João Ribeiro, é o autor didático mais investigado em pesquisas acadêmicas, nas quais é tido como o inaugurador da terceira geração de autores do gênero e marco na historiografia escolar (BITTENCOURT, 1993; GASPARELLO, 2002). João Ribeiro inovou no campo historiográfico e pedagógico influenciando outros autores didáticos. Joaquim Ribeiro, filho de João Ribeiro e responsável pelas reedições e ampliações de História do Brasil, reproduziu, como chamativo na $14^{\text {a }}$ edição, 1953, a seguinte afirmação de Libânio Guedes: João Ribeiro realizou uma verdadeira "revolução copernicana" na reconstrução do nosso passado histórico.

Enquanto autor didático, lembrando que também exerceu as atividades de jornalista, gramático, professor, pintor e tradutor, o título História do Brasil lhe garantiu destaque na historiografia e reconhecimento como historiador. Como afirmou Melo (1997, p. 99), História do Brasil "compõe o pano de fundo da construção do Ribeiro acadêmico e literato", concluindo que há completa coerência entre seus trabalhos ${ }^{16}$.

Foi membro do IHGB e da Academia Brasileira de Letras. Imerso nas campanhas republicanas e abolicionistas, João Ribeiro escreveu artigos e colaborou

\footnotetext{
${ }^{14}$ Conforme indicação na contracapa do livro.

15 A Editora Francisco Alves publica as edições posteriores do autor.

${ }^{16}$ Professor em colégios particulares desde 1881, como São Pedro de Alcântara e Alberto Brandão, em 1887 João Ribeiro inscreveu-se no concurso no Colégio Pedro II para a cadeira de Português, sendo nomeado para a cadeira de História Universal e do Brasil. Foi professor na Escola Dramática do Distrito Federal. Joaquim Ribeiro dizia que a popularidade do nome de seu pai devia-se as gramáticas que escrevera. Melo (1997) diz que o maior interesse de João Ribeiro residia na crítica literária, história da literatura, estudos de gramática e questões do léxico. Cassiano Ricardo (In: Bosi, 1995) escreve que João Ribeiro foi o verdadeiro precursor do "Modernismo de 1922" ao proclamar as diferenças linguísticas entre Portugal e Brasil. Para concurso no Colégio Pedro II João Ribeiro apresentou a tese Morfologia e colocação dos pronomes.
} 
como redator em jornais como O Globo, Gazeta da Tarde, Correio do Povo e O País e na Revista Sul-Americana ao lado de Felisberto Freire e Sílvio Romero.

Em História do Brasil para o curso superior, "segundo os programas do Colégio Pedro II, $13^{a}$ edição refundida e inteiramente revista e melhorada" (1935, Editora Francisco Alves), consta a lista de outros títulos do autor também publicados pela Francisco Alves: Exame de admissão para os ginásios, História do Brasil "para Ginásios e Escolas Normais, curso superior", História do Brasil "para Escolas Primárias, adaptada para o uso das Escolas do estado de Minas, curso médio", História do Brasil (Rudimentos) "para Escolas Primárias, curso primário", História Antiga; e Gramática portuguesa "para o $1^{\circ}, 2^{\circ}$ e $3^{\circ}$ ano", Dicionário gramatical, Livro de exercícios "para servir com a gramática do $1^{\circ}$ ano", Seleta clássica e frases feitas. Além desses, escreveu História Antiga: o Oriente e a Grécia (1892), História Universal (1918) e História da Civilização (1932).

História do Brasil "adaptada ao ensino primário e secundário, 1900, contém 314 páginas e sete ilustrações”. A "edição das escolas primárias, com estampas”, 1900, contém 122 páginas, 24 capítulos, e "cronologia".

O exemplar acessado é destinado ao curso superior, 1928, $11^{\mathrm{a}}$ edição, 543 páginas, contendo a indicação das reedições do título e apreciações de Araripe Júnior, em português, e padre T. Carlos Teschauer, em alemão, além do prefácio intitulado "Do autor". Os conteúdos do livro foram distribuídos em "unidades temáticas".

\section{História do Brasil para o ensino secundário, de Rocha Pombo}

História do Brasil para o ensino secundário, de Rocha Pombo, foi publicada pela Editora Weiszflog Irmãos, em 1918. O título foi reeditado 21 vezes, a última reedição é de 1941.

José Francisco da Rocha Pombo (1857-1933) foi jornalista, professor, político, poeta e historiador. Em 1886 elegeu-se deputado provincial pelo Partido Conservador (QUELUZ, 1998). Bacharelou-se em Ciências Jurídicas e Sociais pela Faculdade de Direito do Rio em 1901. Iniciou-se no jornalismo ao fundar e dirigir O Povo, em cujas páginas fez as campanhas abolicionista e republicana. Ao lado de Pedro do Couto e João Ribeiro, republicanos convictos, Rocha Pombo via os marcos definidores do progresso no fim da monarquia e na ascensão do regime republicano ${ }^{17}$.

Rocha Pombo lecionou no Colégio Pedro II e na Escola Normal do Rio de Janeiro. Foi membro do IHGB e terceiro membro da $39^{\text {a }}$ cadeira da Associação Brasileira de Letras (ABL), mas não chegou a ser empossado. Em 1892 propôs a criação de uma universidade no Paraná ${ }^{18}$. Era conhecido como historiador dedicado ao estudo da formação da nacionalidade brasileira. Serviu-se dos materiais levantados e publicados por outros historiadores para escrever seus livros (GOMES, 1999).

\footnotetext{
${ }^{17}$ Cf. Piloto (1940), Hardman (1984) e Gomes (1999).

${ }^{18}$ Obteve do governo do Paraná a edição de lei em 1892 para criar uma universidade, mas esta não se concretizou. Cf. Campos (2006). O Dicionário biobibliográfico de membros da Academia Brasileira de Letras - I informa que em 1912, Rocha Pombo fundou uma Universidade no Paraná, de duração efêmera. Cf. Martins (2006).
} 
Escreveu História do Brasil, 10 volumes, escritos e publicados entre 1905 e 1917; Nossa Pátria, título de larga repercussão, editado em 1917 e reeditado até 1970, totalizando 8 edições e 452 mil exemplares (LUCCHESI, 2004); História do Rio Grande do Norte (1922); História de São Paulo (resumo didático) (1919); História do Paraná (1930 e 1934); História do Brasil: curso superior (1925); História Universal (1930) e História da América (1900 a 1925).

Garcia (1934), no discurso de posse na ABL, ao suceder Rocha Pombo, dizia "não há como desconhecer o extraordinário mérito" de História do Brasil em 10 volumes de Rocha Pombo, cuja "utilidade provada, os serviços prestados aos estudiosos, que a estimam entre todas as congêneres" ${ }^{19}$. O livro foi criticado por João Ribeiro, que o definiu como "difuso, frio, raras vezes ameno, de leitura difícil", mas com informações úteis. Para Caldas (2005, p. 84), "História do Brasil para o ensino secundário é uma compilação de sua História do Brasil (10 volumes)".

O exemplar acessado de História do Brasil para o ensino secundário, “com muitos mapas históricos e gravuras explicativas", pertence a $19^{\mathrm{a}}$ edição, publicado pela Editora Melhoramentos, 1925 [?]. 317 páginas e 195 ilustrações.

\section{Epítome de História do Brasil, de Jonathas Serrano}

Epítome de História do Brasil, de Jonathas Serrano foi editado pela Editora F. Briguiet \& Cia, 1933.

Jonathas Arcanjo da Silveira Serrano (1885-1944) formou-se em Direito, mas dedicou-se ao ensino de História no Colégio Pedro II e na Escola Normal do Rio de Janeiro. Seus livros contribuíram para a constituição de uma pedagogia da História, dado seu interesse pelo método, o "como se ensina". Igualmente a Araripe Júnior dizia: "o método é a maravilha da escola e a delícia do professor" ${ }^{20}$. Atuou em prol da educação juntamente com Afrânio Peixoto, Fernando de Azevedo, Francisco Campos, Lourenço Filho e Gustavo Capanema, dentre outros. Fez parte da comissão de elaboração do anteprojeto da reforma da instrução no Distrito Federal liderada por Fernando de Azevedo. Também ocupou a direção da Escola Normal do Distrito Federal e subdiretoria técnica da Diretoria Geral da Instrução Publica e presidiu a ABE.

Publicou Epítome de História Universal, 1912, adotado no Colégio Pedro II, Escola Normal do Distrito Federal e em outras instituições de ensino. Em 1919 o livro alcançava a tiragem do $12^{\circ}$ milheiro, em 1943 a $20^{\mathrm{a}}$ edição. A última edição, $24^{\mathrm{a}}$, é de 1954. O livro foi considerado um ensaio da nova orientação dos estudos históricos. ${ }^{21}$

Em 1917 publicou Metodologia da História na aula primária. O "livrinho" foi considerado por Afrânio Peixoto como de "utilidade para normalistas, professores, estudiosos, educadores e curiosos". Publicou História do Brasil, impresso na França e publicado em 1931, com tiragem reduzida de 200 exemplares, tendo em vista o alto

\footnotetext{
19 Discurso de Rodolfo Garcia em posse na ABL. Disponível em: <http://www.academia.org.br/abl/cgi/cgilua.exe/sys/start.htm?infoid=8478\&sid=350>. Acesso em: 21 out. 2010.

${ }^{20}$ Cf. Moreira (2008).

${ }^{21}$ Em 1914 publicou Um vulto de 1817, analisando a participação de Domingos José Martins, seu tio-avô, na revolução de 1817. Zanatta (2005, p. 32) afirma que tal interpretação da revolução de 1817 "pode ter influenciado Jonathas Serrano em sua participação nas mudanças educacionais, levando-o a se assumir como católico convicto e ao mesmo tempo partidário da modernidade educativa e social".
} 
custo devido a quantidade de páginas, 580, ilustrações e mapas, 121. Revisado por Lucinda Coutinho de Mello Coelho, o livro foi reeditado em 1968.

Defensor do uso de outros meios de ensino que não apenas o livro didático publicou em 1930, com Venâncio Filho, Cinema e educação. Como entusiasta da Escola Nova escreveu Escola Nova, palavras serenas num debate apaixonado, 1932, assumindo postura conciliadora entre "católicos" e "modernistas". Em 1935 publicou Como se ensina História, livro de metodologia aplicada ${ }^{22}$.

Epítome de História do Brasil assemelha-se a História do Brasil do autor, mas não mero resumo. No dizer de Jonathas Serrano "a diferença é muito mais de plano de exposição, de estrutura interna, de aplicação metodológica do que meramente de volume, calculado em páginas" (SERRANO, 1941, p. 1). O exemplar acessado pertente a $3^{\text {a }}$ edição, 1941. Contêm 251 páginas, 14 capítulos, 47 ilustrações, 43 retratos, quadros cronológicos e sincrônicos, leituras "complementares" e exercícios ao final dos capítulos.

\section{História do Brasil, de Basílio de Magalhães}

Basílio de Magalhães (1874-1957), historiador, jornalista, político, folclorista e professor, formou-se em engenharia. Desde estudante difundia ideias republicanas ${ }^{23}$. Lecionou História da Civilização em diversas instituições: Colégio Pedro II, Ginásio de Campinas, Escola Normal do Distrito Federal e Escola Nacional de Belas Artes. A pedido do presidente Wenceslau Braz dirigiu a Biblioteca Nacional e ocupou interinamente a direção do Arquivo Nacional.

O trabalho que apresentou no $1^{\circ}$ Congresso de História Nacional do IHGB, 1914, influenciou a indicação de Max Fleiuss e Liberato Bittencourt para que Basílio de Magalhães fosse acolhido sócio-correspondente da instituição.

Dentre outros, publicou O folclore no Brasil, 1939. Na prestigiosa "Coleção Brasiliana" da Companhia Editora Nacional publicou: O café: na história, no folclore e nas belas-artes, Expansão geográfica do Brasil colonial, Estudos da história do Brasil e História do comércio, indústria e agricultura.

Como autor didático publicou Lições de História do Brasil (1895), Quadros de História Pátria (1918) em coautoria com Max Fleiuss ${ }^{24}$, História da Civilização (desde 1939), Estudos de História do Brasil (1940), História do Brasil, uma reedição em coautoria com Jaime Coelho (1958), História administrativa e econômica do Brasil (1951) e História da América (1952). Esses títulos tiveram larga aceitação entre 1930 e 1950.

Os exemplares de História do Brasil acessados pertencem, respectivamente, a $3^{\text {a }}$ edição, Editora Francisco Alves, 1958. Coautoria Jayme Coelho, destinada a $2^{\text {a }}$ série dos cursos clássico e científico. 262 páginas, 9 mapas, 10 capítulos; e a $1^{\text {a }}$ edição, Editora Francisco Alves, 1942, segundo volume, para a $5^{\text {a }}$ série do curso secundário. 222 páginas, 14 capítulos, 83 ilustrações, das quais três são mapas.

\section{História do Brasil, de Joaquim Silva}

\footnotetext{
${ }^{22}$ Mais informações sobre Como se ensina História, em Moreira (2008).

${ }^{23}$ Cf. Pinto (2000).

${ }^{24}$ Livro analisado por Gasparello (2002).
} 
Joaquim Silva (1880-1966) foi professor em diversas instituições de ensino paulista: Liceu Nacional Rio Branco, Colégio Madre Cabrini, Colégio São Luiz e Ginásio das Cônegas de Santo Agostinho.

É o autor com maior número de didáticos de História vendidos nas décadas de 1930 e 1940, editados pela Companhia Editora Nacional.

No fichário da Biblioteca Nacional constam os títulos didáticos de Joaquim Silva, (RESNIK, 1992). Entre os 55 títulos do autor constantes no LIVRES há títulos relacionados a história geral, da civilização, da América e história do Brasil.

Foram dois os exemplares acessados. O primeiro, História do Brasil para o terceiro ano ginasial, $8^{\text {a }}$ edição, 1943, "de acordo com o último programa oficial". O segundo, História do Brasil para o quarto ano ginasial, $11^{a}$ edição revista e aumentada, 1944, "de acordo com o último programa oficial", 213 páginas. Ambos, com quadros sincrônicos, ilustrações, "datas notáveis", "sumário" e apontamentos "para exercício escrito".

\section{CONSIDERAÇÕES FINAIS}

Os processos de localização, seleção e análise dos livros didáticos devem levar em consideração tratar-se de objeto de múltiplas facetas, como afirma Bittencourt (1993), o que significa dizer, que o livro didático é um instrumento de políticas governamentais, portanto, imbuído de valor ideológico e cultural; produto editorial que obedece a técnicas de fabricação e interesses de mercado; e depositário dos conteúdos educacionais. Desse modo, o estudo histórico do livro didático não é simples nem imediato, requer cuidados e exige método próprio de análise ${ }^{25}$. Instrumento pedagógico inscrito em uma longa tradição, é inseparável da sua elaboração, utilização das estruturas, métodos e condições do ensino de seu tempo (CHOPPIN, 1992), o que significa considerar o contexto, os programas e currículos vigentes no período de uso de cada obra.

Atentando-se a perspectiva da nova história cultural, conforme Chartier (1988), devemos nos atentar ainda, para as intenções e dispositivos próprios da transformação do escrito em livro/impresso. Considerando, como lembra Paulilo (2012), que a ênfase da análise "nos suportes materiais da produção e da circulação dos impressos e na materialidade das práticas e usos da leitura vem se tornando indispensável" ao estudo dos livros didáticos, com o intuito de "perceber as marcas dos usos prescritos para os destinatários visados". (PAULILO, 2012, p. 182).

No entanto, como lembra Tiana Ferrer (2017) mesmo que consigamos dispor, dos livros didáticos publicados em uma determinada época, é difícil saber com precisão como foram utilizados em salas de aula por professores e alunos. Badanelli Rubio (2008) complementa que uma das dificuldades que apresenta a investigação sobre livros didáticos é poder conhecer a repercussão que tiveram os textos e comprovar se realmente foram ou não usados nas salas de aulas. Entrecruzar obras didáticas com os cadernos escolares, como propõem Mahamud e Badanelli neste dossiê, parece ser um exercício eficiente na busca dos contextos de transmissão e recepção dos conteúdos dos livros didáticos.

\footnotetext{
${ }^{25}$ Cf. Tiana Ferrer (2017), Collados Cardona (2008) e Badanelli Rubio (2008).
} 


\section{REFERÊNCIAS}

BADANELLI RUBIO, A. M. B. Ser español en imágenes: la construcción de la identidad nacional a través de las ilustraciones de los textos escolares (1940-1960). Historia de la Educación, Revista Interuniversitaria. Salamanca, n. 27, 2008, pp. 137213.

BITTENCOURT, C. M. F. Pátria, civilização e trabalho. São Paulo: Loyola, 1990.

Livro didático e conhecimento histórico: uma história do saber escolar. São Paulo, 1993. Tese (Doutorado em História Social) - Universidade de São Paulo, São Paulo, 1993.

BUENO, J. B. G. Representações iconográficas em livros didáticos de História. 2003, Campinas, 2003. Dissertação (Mestrado em Educação) - Universidade Estadual de Campinas, 2003.

CALDAS, K. R. Entre história e memória: os manuais escolares e os projetos de formação nacional (1912-1949). Goiânia, 2005. Dissertação (Mestrado em História) Universidade Federal de Goiás, Goiânia, 2005.

CHOPPIN, A. L'histoire des manuels scolaires: une approche globale. Histoire de l'Éducation, Paris, n. 9, p 1-25, 1980.

Os livros didáticos de ontem a hoje: o exemplo da França. In. MOREIRA, K. H.; HERNANDÉZ DÍAZ, J. M. (Org.). História da educação e livros didáticos. Campinas-SP: Pontes Editores, 2017, p. 81-124.

História dos livros e das edições didáticas: sobre o estado da arte. Educação e Pesquisa, São Paulo, v. 30, set.-dez. 2004.

COLLADOS CARDONA, E. El concepto de dibujo y su práctica en los libros de texto de educación primaria publicados en España en el periodo comprendido entre 19151990. Historia de la Educación, Revista Interuniversitaria, Salamanca, n. 27, 2008, pp. 323-346.

DELGADO, B. Los libros de texto como fuente para la Historia de la Educación. Historia de la Educación, Revista Interuniversitaria, Salamanca, n. 2, p. 353-258, 1983. 
DEMORI, M. Livros Didáticos e representações: a idéia de raças nos manuais de história do Brasil para o ensino secundário, 1937-1947. Franca, 2000. Dissertação (Mestrado em História) - Faculdade de História, Direito e Serviço Social, Universidade Estadual Paulista.

ESTEBAN MATEO, L. Los catálogos de librería y material de enseñanza como fuente iconográfica y literario-escolar. Historia de la Educación, Revista Interuniversitaria, Salamanca, n. 16, p. 17-46,1997.

GASPARELLO, A. Construtores de identidades: os compêndios de História do Brasil do Colégio Pedro II (1838-1920). São Paulo, 2002. Tese (Doutorado em Educação). Pontifícia Universidade Católica de São Paulo, São Paulo, 2002.

GOMES, A. de C. História e historiadores. 2. ed. Rio de Janeiro: Ed. FGV, 1999.

HAIDAR, M. de L. M. O ensino secundário no Brasil Império. 2. ed. São Paulo: EDUSP, 2008.

HANSEN, P. S. Feições e fisionomia: a história do Brasil de João Ribeiro. Rio de Janeiro: Acess, 2000.

HOLANDA, G. de. Um quarto de século de programas e compêndios de História para o ensino secundário brasileiro (1931-1956). Rio de Janeiro: INEP/CBPE, 1957.

LUCCHESI, F. A história como ideal: reflexões sobre a obra de José Francisco da Rocha Pombo. São Paulo, 2004. Dissertação (Mestrado) Faculdade de Filosofia, Letras e Ciências Humanas - Universidade de São Paulo, São Paulo, 2004.

MATTOS, S. R. de. O Brasil em lições. A história como disciplina escolar em Joaquim Manuel de Macedo. Rio de Janeiro: Access, 2000.

MELO, C. B. de. Senhores da história: a construção do Brasil em dois manuais didáticos de História na segunda metade do século XIX. São Paulo, 1997. Tese (Doutorado em Educação), Universidade de São Paulo, São Paulo, 1997.

MOREIRA, K. H. O ensino de História do Brasil no contexto republicano de 1889 a 1950 pelos livros didáticos: análise historiográfica e didático-pedagógica. $2011236 \mathrm{f}$. Tese (Doutorado em Educação Escolar) - Universidade Estadual Paulista, Faculdade de Ciências e Letras, Campus de Araraquara, São Paulo, 2011. 
Sensibilidades e sociabilidades em "Como se ensina História" (1935) de

Jonathas Serrano. In: IV SIMPÓSIO NACIONAL DE HISTÓRIA CULTURAL. 2008, Goiânia. Anais... Goiânia: Ed. da UCG, 2008. v. 1. p. 382-383.

MOREIRA, K. H., SILVA, M. Um inventário: o livro didático de história em pesquisas (180-2005). São Paulo: Ed. da UNESP, 2011.

OLIVEIRA, I. F. de. A pedagogia da história de Jonathas Serrano para o ensino secundário brasileiro (1913-1935). São Paulo, 2006. Tese (Doutorado Educação). Pontifícia Universidade Católica de São Paulo, São Paulo, 2006.

PINTO A. P. M. A estratégia de memória nacional na obra de Basílio Magalhães. 2000, Rio de Janeiro. Dissertação (Mestrado em Memória Social e Documento) Unirio.

QUELUZ, Gilson L. Rocha Pombo: Romantismo e utopias - 1880/1905. Curitiba: Aos Quatro Ventos, 1998.

RESNIK, L. Tecendo o amanhã (a história do Brasil no ensino secundário: programas e livros didáticos. (1931-1945). Rio de Janeiro, 1992. Dissertação (Mestrado em História) -Universidade Federal Fluminense, Rio de Janeiro, 1992.

RIBEIRO, R. R. Colônia(s) de identidades: discursos sobre a raça nos manuais escolares de História do Brasil. Campinas, 2004. Dissertação (Mestrado em História) Universidade Estadual de Campinas, Campinas, 2004.

RODRIGUES, J. E. D. Memória fora de foco. A fotografia no livro didático de História do Brasil. São Paulo, 2004. Dissertação (Mestrado em Educação) - Universidade Católica de São Paulo, São Paulo, 204.

SILVA FILHO, J. B. da. Representações sobre negros nos discursos verbais e iconográficos de livros didáticos de história. Belo Horizonte, 2005. Dissertação (Mestrado em Educação), Universidade Federal de Minas Gerais, Belo Horizonte, 2005.

THOMPSON, A. A fábrica de heróis uma análise dos heróis nacionais nos livros didáticos de historia do Brasil. Rio de Janeiro, 1989. Dissertação (Mestrado em Antropologia Social). Universidade Federal do Rio de Janeiro, Rio de Janeiro, 1989.

TIANA FERRER, A. O projeto Manes e a investigação histórica sobre os livros didáticos (séculos XIX e XX). In. MOREIRA, K. H.; HERNANDÉZ DÍAZ, J. M. (Org.). História da educação e livros didáticos. Campinas-SP: Pontes Editores, 2017, p. 23-48. 
VECHIA, A.; LORENZ, K. M. (Orgs.). Programas de ensino da escola secundária brasileira: 1850-1951. Curitiba: Ed. do Autor, 1998.

VIDAL, M. C. F. R. Jonathas Serrano: limites e possibilidades no ensino de História do Brasil nos anos 30. Rio de Janeiro, 2005. Dissertação (Mestrado em História).

Universidade Federal Fluminense, Rio de Janeiro, 2005.

ZANATTA, R. M. Jonathas Serrano e a escola nova no Brasil: raízes católicas na corrente progressista. São Paulo, 2005. Tese (Doutorado em Educação) Universidade de São Paulo, São Paulo, 2005.

\section{Fontes}

MACEDO, J. M. Lições de História do Brasil. 9. ed. Rio de Janeiro: Garnier, 1907.

MAGALHÃES, B. História do Brasil. Rio de Janeiro: Francisco Alves, 1942.

História do Brasil. Curso clássico e científico. $2^{\text {a }}$ Série. 3. ed. Rio de Janeiro: Francisco Alves, 1958.

RIBEIRO, J. História do Brasil curso superior. 11. ed. Rio de Janeiro: Francisco Alves, 1928.

ROCHA POMBO. Dicionário de sinônimos da língua portuguesa. Rio de Janeiro: Francisco Alves, 1914.

História do Brasil para o ensino secundário. 19. ed. São Paulo:

Melhoramentos, 1925?.

Nossa Pátria. São Paulo: Melhoramentos, 1925. [1. ed.: Weiszflog Irmãos, 1917].

SERRANO, J. Epítome de História do Brasil. 3. ed. Rio de Janeiro: F. Briguiet \& Cia editores, 1941.

SILVA, J. História do Brasil para o terceiro ano ginasial. 8. ed. São Paulo: Nacional, 1943. 
. História do Brasil para o quarto ano ginasial. 11. ed. São Paulo: Nacional, 1944.

\section{APÊNDICE}

\section{Levantamento de livros didáticos de História do Brasil para o Ensino Secundário (1889-1950)}

O levantamento abaixo apresenta os dados dos livros didáticos localizados por: autor, título, ano, edição/editora e a(s) fonte(s) de localização (Banco de livros escolares - LIVRES; Holanda - 1957; Vechia e Lorenz - 1998; e/ou Moreira e Silva - 2011).

\begin{tabular}{|c|c|c|c|}
\hline AUTOR & $\begin{array}{c}\text { TÍTULO DO LIVRO } \\
\text { DIDÁTICO }\end{array}$ & ANO/EDIÇÃO/EDITORA & FONTE \\
\hline $\begin{array}{l}\text { Afonso Guerreiro } \\
\text { LIMA }\end{array}$ & Noções de História do Brasil & $\begin{array}{l}1942 \text { 10. ed. Livraria do } \\
\text { Globo. Porto Alegre-RS }\end{array}$ & LIVRES \\
\hline Afrânio Peixoto & História do Brasil & $\begin{array}{l}1940 \text { Lello \& Irmãos } \\
\text { Editores, Porto } \\
\text { 1944, Ed. Nacional }\end{array}$ & $\begin{array}{l}\text { Moreira e } \\
\text { Silva (2011) } \\
\text { LIVRES }\end{array}$ \\
\hline \multirow{2}{*}{ Alfredo GOMES } & $\begin{array}{c}\text { História do Brasil para a } 4^{a} \\
\text { série fundamental }\end{array}$ & $\begin{array}{l}\text { 1940, 1941, 2. ed. Edições } \\
\text { Brasil }\end{array}$ & $\begin{array}{l}\text { Holanda } \\
(1957) \\
\text { Moreira e } \\
\text { Silva (2011) }\end{array}$ \\
\hline & $\begin{array}{l}\text { História do Brasil para a } 5^{a} \\
\text { série fundamental }\end{array}$ & $\begin{array}{l}\text { 1949, 1941, 2. ed. Edições } \\
\text { Brasil }\end{array}$ & $\begin{array}{c}\text { Holanda } \\
(1957) \\
\text { Moreira e } \\
\text { Silva (2011) }\end{array}$ \\
\hline $\begin{array}{l}\text { Alfredo Moreira } \\
\text { PINTO }\end{array}$ & Epitome da História do Brasil & $\begin{array}{c}\text { 1890, 2. Ed. Livraria } \\
\text { Clássica de Alves; } \\
\text { 1892, 3. ed. Livraria } \\
\text { Clássica de Alves }\end{array}$ & $\begin{array}{l}\text { Moreira e } \\
\text { Silva (2011) } \\
\text { LIVRES }\end{array}$ \\
\hline $\begin{array}{l}\text { Alfredo Balthazar da } \\
\text { SILVEIRA }\end{array}$ & Lições de História do Brasil & 1924, Francisco Alves & LIVRES \\
\hline $\begin{array}{c}\text { Aníbal } \\
\text { MASCARENHAS }\end{array}$ & Curso de História do Brasil & $\begin{array}{l}\text { 1898, Livraria do Povo- } \\
\text { Quaresma \& C. }\end{array}$ & $\begin{array}{c}\text { LIVRES } \\
\text { Moreira e } \\
\text { Silva (2011) } \\
\end{array}$ \\
\hline \multirow{2}{*}{ Artur Gaspar VIANA } & $\begin{array}{l}\text { História do Brasil. Primeiro } \\
\text { Volume }\end{array}$ & 1944, Editora do Brasil & $\begin{array}{c}\text { Moreira e } \\
\text { Silva (2011) }\end{array}$ \\
\hline & $\begin{array}{l}\text { História do Brasil. Segundo } \\
\text { Volume }\end{array}$ & 1944, Editora do Brasil & $\begin{array}{c}\text { Holanda } \\
(1957)\end{array}$ \\
\hline \multirow{5}{*}{ Ary da MATTA } & $\begin{array}{l}\text { História do Brasil: para a } \\
\text { terceira série ginasial }\end{array}$ & $\begin{array}{l}1947 \text { 3.ed.; 1945, 4. ed. } \\
\text { Editora Nacional }\end{array}$ & $\begin{array}{l}\text { Moreira e } \\
\text { Silva (2011) } \\
\text { LIVRES } \\
\end{array}$ \\
\hline & História do Brasil & 195-2.ed. & LIVRES \\
\hline & $\begin{array}{l}\text { Curso básico de História do } \\
\text { Brasil: para o terceiro ano do } \\
\text { curso comercial básico }\end{array}$ & 1959 & LIVRES \\
\hline & $\begin{array}{l}\text { História do Brasil (1 }{ }^{a} \text { série } \\
\text { ginasial) }\end{array}$ & 1953, Editora Nacional & $\begin{array}{c}\text { Moreira e } \\
\text { Silva (2011) }\end{array}$ \\
\hline & História do Brasil para a & 1945, Editora Nacional & Holanda(1957) \\
\hline
\end{tabular}




\begin{tabular}{|c|c|c|c|}
\hline & terceira série ginasial. & & \\
\hline & $\begin{array}{l}\text { História do Brasil ( } 4^{a} \text { série } \\
\text { ginasial) }\end{array}$ & 1948- Nacional & $\begin{array}{l}\text { Moreira e } \\
\text { Silva (2011) } \\
\text { Holanda } \\
\text { (1957) }\end{array}$ \\
\hline A. Duarte ALMEIDA & História do Brasil & $\begin{array}{l}\text { 1936, Lisboa: João Romano } \\
\text { Torres \& Cia }\end{array}$ & $\begin{array}{c}\text { Moreira e } \\
\text { Silva (2011) } \\
\end{array}$ \\
\hline \multirow{8}{*}{$\begin{array}{c}\text { Basílio de } \\
\text { MAGALHÃES }\end{array}$} & Lições de História do Brasil & 1895, Tipografia Ribeiro & $\begin{array}{l}\text { Moreira e } \\
\text { Silva (2011) }\end{array}$ \\
\hline & História do Brasil & $\begin{array}{l}1942,1943 \\
\text { 1945, 3. ed. Francisco Alves } \\
(1949,1951)\end{array}$ & $\begin{array}{c}\text { Moreira e } \\
\text { Silva }(2011) \\
\text { Holanda } \\
(1957) \\
\text { LIVRES }\end{array}$ \\
\hline & $\begin{array}{l}\text { História do Brasil ( } 1^{a} \text { série } \\
\text { ginasial) }\end{array}$ & $\begin{array}{c}1952,1953 \\
\text { Francisco Alves }\end{array}$ & $\begin{array}{c}\text { Moreira e } \\
\text { Silva (2011) }\end{array}$ \\
\hline & $\begin{array}{c}\text { História do Brasil ( } 3^{a} \text { série } \\
\text { ginasial) }\end{array}$ & $\begin{array}{c}1945 \text { Francisco Alves } \\
1951 \text { 5. ed. Francisco Alves }\end{array}$ & $\begin{array}{c}\text { Moreira e } \\
\text { Silva (2011) } \\
\text { Holanda } \\
(1957) \\
\end{array}$ \\
\hline & História do Brasil: $4^{a}$ série & 1945 -Francisco Alves & $\begin{array}{c}\text { Moreira e } \\
\text { Silva (2011) } \\
\text { LIVRES } \\
\text { Holanda } \\
(1957) \\
\end{array}$ \\
\hline & $\begin{array}{c}\text { História do Brasil para a } 2^{a} \\
\text { série dos cursos clássico e } \\
\text { cientifico }\end{array}$ & 1952 RJ: Francisco Alves & $\begin{array}{c}\text { Moreira e } \\
\text { Silva (2011) }\end{array}$ \\
\hline & $\begin{array}{c}\text { História do Brasil para a } 2^{a} \\
\text { série dos curso clássico e } \\
\text { cientifico }\end{array}$ & 1957 RJ: Francisco Alves & $\begin{array}{c}\text { Moreira e } \\
\text { Silva (2011) }\end{array}$ \\
\hline & $\begin{array}{c}\text { Compêndio de História do } \\
\text { Brasil }\end{array}$ & 1945 Francisco Alves & $\begin{array}{c}\text { Moreira e } \\
\text { Silva (2011) }\end{array}$ \\
\hline $\begin{array}{c}\text { Basílio de } \\
\text { MAGALHÃES e } \\
\text { Max FLEIUSS }\end{array}$ & Quadros de História Pátria & $\begin{array}{l}\text { 1918, Editor A. J. de } \\
\text { Castilho, } \\
\text { 1919, Imprensa Nacional }\end{array}$ & $\begin{array}{c}\text { Moreira e } \\
\text { Silva (2011) } \\
\text { Vechia e } \\
\text { Lorenx (1998) } \\
\end{array}$ \\
\hline Felisberto FREIRE & $\begin{array}{l}\text { História do Brasil } 1^{\circ} \text { Grau } \\
\text { (Secundário) }\end{array}$ & $\begin{array}{l}\text { 1896, Livraria Clássica } \\
\text { Alves }\end{array}$ & $\begin{array}{c}\text { Moreira e } \\
\text { Silva (2011), } \\
\text { LIVRES }\end{array}$ \\
\hline $\begin{array}{l}\text { Frei Vicente do } \\
\text { SALVADOR }\end{array}$ & História do Brasil & 1918, Weiszflog Irmãos & $\begin{array}{c}\text { Moreira e } \\
\text { Silva (2011) }\end{array}$ \\
\hline & $\begin{array}{l}\text { Pequena História do Brasil: } \\
\text { ensino primário e secundário }\end{array}$ & 1918, 4. ed. & LIVRES \\
\hline FTD & $\begin{array}{l}\text { Elementos de História do } \\
\text { Brasil: para uso dos ginásios }\end{array}$ & $\begin{array}{l}\text { 1925, Paulo de Azevedo } \\
\text { s/d Francisco Alves }\end{array}$ & $\begin{array}{c}\text { LIVRES } \\
\text { Moreira e } \\
\text { Silva (2011) } \\
\end{array}$ \\
\hline Hélio VIANNA & $\begin{array}{c}\text { História do Brasil: para a } 4^{a} \\
\text { série, de acordo com o } \\
\text { programa oficial }\end{array}$ & $\begin{array}{l}\text { 1945. Livraria José } \\
\text { Olympio Ed. RJ }\end{array}$ & $\begin{array}{l}\text { LIVRES } \\
\text { Holanda } \\
(1957)\end{array}$ \\
\hline & $\begin{array}{c}\left.\text { História do Brasil (para a 3 }{ }^{\mathrm{a}}\right) \\
\left(4^{\mathrm{a}} \text { série }\right)\end{array}$ & $\begin{array}{c}\text { 1950 - Nacional } \\
\text { 1942, José Olympio }\end{array}$ & $\begin{array}{c}\text { Moreira e } \\
\text { Silva (2011) }\end{array}$ \\
\hline
\end{tabular}




\begin{tabular}{|c|c|c|c|}
\hline & História do Brasil & 1967,6 ed. & LIVRES \\
\hline & $\begin{array}{c}\text { História do Brasil Colonial ( } 3^{\mathrm{a}} \\
\text { série) }\end{array}$ & 1945, 1950, Nacional & $\begin{array}{c}\text { Moreira e } \\
\text { Silva (2011) } \\
\text { Holanda } \\
\text { (1957) }\end{array}$ \\
\hline & $\begin{array}{l}\text { História do Brasil } 3^{a} \text { ano } \\
\text { colegial }\end{array}$ & 1952 - Nacional & $\begin{array}{c}\text { Holanda } \\
(1957)\end{array}$ \\
\hline & $\begin{array}{c}\text { História do Brasil (Período } \\
\text { colonial) }\end{array}$ & 1967 SP: Melhoramentos & $\begin{array}{c}\text { Moreira e } \\
\text { Silva }(2011)\end{array}$ \\
\hline João de Lyra Tavares & Pontos de História do Brasil & $\begin{array}{c}\text { 1912, Imprensa Oficial - } \\
\text { Paraíba }\end{array}$ & LIVRES \\
\hline \multirow{2}{*}{$\begin{array}{l}\text { João Pereira } \\
\text { VITÓRIA }\end{array}$} & História do Brasil. $3^{\mathrm{a}}$ série. & $\begin{array}{l}\text { Rio de Janeiro: Francisco } \\
\text { Alves, s.d. }\end{array}$ & $\begin{array}{c}\text { Holanda } \\
(1957)\end{array}$ \\
\hline & História do Brasil. $4^{\mathrm{a}}$ série & $\begin{array}{c}\text { Rio de Janeiro: Francisco } \\
\text { Alves, } 1946\end{array}$ & $\begin{array}{l}\text { Holanda } \\
(1957)\end{array}$ \\
\hline \multirow{3}{*}{ João RIBEIRO } & História do Brasil & 1900 & LIVRES \\
\hline & $\begin{array}{c}\text { História do Brasil: curso } \\
\text { superior }\end{array}$ & $\begin{array}{c}\text { 1900, 1912, 1923, 10. ed., } \\
\text { 1926, 1929, 19. ed. } \\
\text { Francisco Alves }\end{array}$ & $\begin{array}{c}\text { Moreira e } \\
\text { Silva }(2011) \\
\text { LIVRES }\end{array}$ \\
\hline & História do Brasil & $\begin{array}{l}\text { 1923, 10. ed., Francisco } \\
\text { Alves } \\
\text { 1953. Livraria São José. }\end{array}$ & $\begin{array}{c}\text { Moreira e } \\
\text { Silva }(2011)\end{array}$ \\
\hline $\begin{array}{c}\text { João RIBEIRO } \\
\text { Joaquim RIBEIRO }\end{array}$ & $\begin{array}{l}\text { História do Brasil: curso } \\
\text { superior }\end{array}$ & $\begin{array}{l}\text { 1935. } 17 \text { ed. F. Alves } \\
\text { 1954 15.ed. } \\
1966 \text { 19.ed. Francisco } \\
\text { Alves. RJ }\end{array}$ & $\begin{array}{c}\text { Moreira e } \\
\text { Silva (2011) } \\
\text { LIVRES }\end{array}$ \\
\hline $\begin{array}{l}\text { Joaquim Manuel de } \\
\text { MACEDO }\end{array}$ & Lições de História do Brasil & $\begin{array}{c}\text { 1. ed. 1861; } 1863 \\
\text { 1914 RJ: Garnier } \\
\text { Última edição } 1928\end{array}$ & $\begin{array}{l}\text { Moreira e } \\
\text { Silva }(2011) \\
\text { LIVRES }\end{array}$ \\
\hline \multirow{6}{*}{ Joaquim SILVA } & $\begin{array}{l}\text { História do Brasil: para o } \\
\text { quarto ano ginasial }\end{array}$ & $\begin{array}{l}1941 \text { 2.ed.; } 19423 . \text { ed.; } \\
\text { 1943, 3. ed.; 1943, 7. ed.; } \\
1946 \text { 15. ed.; } 1952 \text { 30. ed.; } \\
1954 \text { 7.ed.; } 1958 \text { 27.ed. } \\
\text { Editora Nacional }\end{array}$ & $\begin{array}{c}\text { LIVRES } \\
\text { Moreira e } \\
\text { Silva }(2011)\end{array}$ \\
\hline & $\begin{array}{c}\text { História do Brasil: para o } \\
\text { quinto ano ginasial }\end{array}$ & 1942 3.ed. & LIVRES \\
\hline & $\begin{array}{l}\text { História do Brasil: para o } \\
\text { terceiro ano ginasial }\end{array}$ & $\begin{array}{c}\text { 1943 3.ed. Ed. S/A } \\
\text { 1943 7.ed. } \\
\text { 1946 17.ed. } \\
\text { 1950 31.ed. } \\
\text { 1952, 40. ed. Nacional }\end{array}$ & $\begin{array}{l}\text { Moreira e } \\
\text { Silva (2011) } \\
\text { LIVRES } \\
\text { Holanda } \\
\text { (1957) }\end{array}$ \\
\hline & $\begin{array}{c}\text { História do Brasil: para a } \\
\text { primeira série ginasial }\end{array}$ & $\begin{array}{c}\text { 1951, } 8 \text { ed. Editora } \\
\text { Nacional. } \\
\text { 1952 7.ed. } \\
1953 \text { 21.ed. }-20 . \text { ed. } \\
1955 \text { 34.ed. }-40 . \text { ed. } \\
\text { 1955 40.ed. }\end{array}$ & $\begin{array}{l}\text { Moreira e } \\
\text { Silva (2011) } \\
\text { LIVRES }\end{array}$ \\
\hline & História do Brasil ( $3^{a}$ e $4^{a}$ série $)$ & $\begin{array}{c}\text { 1936, 1941, 2. ed.; } 19423 . \\
\text { ed.; 1943, 3. ed.; 1943, } 7 . \\
\text { ed. Editora Nacional } \\
\quad(1952,1953,1955)\end{array}$ & $\begin{array}{c}\text { LIVRES } \\
\text { Moreira e } \\
\text { Silva }(2011)\end{array}$ \\
\hline & História do Brasil & $\begin{array}{l}1942 \text { 2. ed. Nacional } \\
\text { 1953. 22. ed. Nacional }\end{array}$ & $\begin{array}{c}\text { Moreira e } \\
\text { Silva }(2011)\end{array}$ \\
\hline
\end{tabular}




\begin{tabular}{|c|c|c|c|}
\hline & $\begin{array}{l}\text { História do Brasil curso } \\
\text { colegial }\end{array}$ & 1952, 1963 SP: Nacional & $\begin{array}{l}\text { Moreira e } \\
\text { Silva (2011) }\end{array}$ \\
\hline $\begin{array}{l}\text { Joaquim SILVA \& } \\
\text { J. B. Damasco Penna } \\
\text { (Colaborador) }\end{array}$ & $\begin{array}{c}\text { História do Brasil: para o curso } \\
\text { médio (primeira e segunda } \\
\text { séries) }\end{array}$ & $\begin{array}{l}1965 \text { 18. ed. } \\
\text { (1969 22. ed.) }\end{array}$ & LIVRES \\
\hline & Epítome de História do Brasil & $\begin{array}{l}\text { 1933, 1939, 1941, 3. ed., } \\
\text { 1944, 4. ed., F. Briguiet \& } \\
\text { Cia, RJ }\end{array}$ & $\begin{array}{l}\text { LIVRES } \\
\text { Moreira e } \\
\text { Silva (2011) }\end{array}$ \\
\hline Jonathas SERRANO & $\begin{array}{c}\text { História do Brasil. } 1^{\circ} \text { Vol. } \\
\text { Terceira série do curso ginasial. }\end{array}$ & F. Briguiet, 1945. & $\begin{array}{c}\text { Holanda } \\
(1957)\end{array}$ \\
\hline Ionathas SERR ANO & $\begin{array}{l}\text { História do Brasil. } 2^{\circ} \text { Vol. } \\
\text { Quarta série. O Império e a } \\
\text { República. }\end{array}$ & F. Briguiet, 1946. & $\begin{array}{l}\text { Holanda } \\
\text { (1957) }\end{array}$ \\
\hline (Colaboradores: & $\begin{array}{c}\text { História do Brasil. Quarta série } \\
\text { do Curso Secundário. }\end{array}$ & $\begin{array}{l}\text { 2. ed. Melhoramentos de } \\
\text { São Paulo, } 1947\end{array}$ & $\begin{array}{c}\text { Holanda } \\
(1957)\end{array}$ \\
\hline $\begin{array}{l}\text { Mchmia Junquelra } \\
\text { Schid; Helena } \\
\text { Sabóia de Medeiros) }\end{array}$ & História do Brasil & $\begin{array}{l}\text { 1931. RJ: F. Briguiet e } \\
\text { Editores }\end{array}$ & $\begin{array}{c}\text { Moreira e } \\
\text { Silva (2011) }\end{array}$ \\
\hline & $\begin{array}{c}\text { História do Brasil (para } 3^{a} \text { e } 4^{a} \\
\text { séries ginasiais) }\end{array}$ & $\begin{array}{c}1945 \\
1946 \\
\text { RJ: F. Briguiet \& Editores }\end{array}$ & $\begin{array}{c}\text { LIVRES } \\
\text { Moreira e } \\
\text { Silva (2011) }\end{array}$ \\
\hline $\begin{array}{c}\text { José F. C. de Sá e } \\
\text { BENEVIDES }\end{array}$ & História do Brasil & $\begin{array}{l}\text { 1912. 3. ed. RJ: Francisco } \\
\text { Alves }\end{array}$ & $\begin{array}{l}\text { Moreira e } \\
\text { Silva (2011) }\end{array}$ \\
\hline $\begin{array}{c}\text { José Maria da Silva } \\
\text { PARANHOS, } \\
\text { BARÃO DO RIO } \\
\text { BRANCO } \\
\text { Em francês, traduzido } \\
\text { por: João Vieira de } \\
\text { Almeida } \\
\end{array}$ & \multirow[t]{2}{*}{ História do Brasil ${ }^{26}$} & 1894, Livraria Teixeira & $\begin{array}{l}\text { Moreira e } \\
\text { Silva (2011) }\end{array}$ \\
\hline $\begin{array}{c}\text { José Bernardino } \\
\text { Paranhos da SILVA } \\
\text { (sobrinho do Barão do } \\
\text { Rio Branco) } \\
\end{array}$ & & 1930, Tip. São Benedito & LIVRES \\
\hline \multirow{4}{*}{$\begin{array}{l}\text { José Francisco } \\
\text { Rocha POMBO }\end{array}$} & História do Brasil & $\begin{array}{l}\text { 1905. Rio de Janeiro } \\
\text { 1918, 1924, 1925, 6. ed. } \\
\text { Weiszflog Irmãos } \\
\end{array}$ & $\begin{array}{c}\text { Moreira e } \\
\text { Silva (2011) } \\
\text { LIVRES } \\
\end{array}$ \\
\hline & $\begin{array}{l}\text { História do Brasil: para o } \\
\text { ensino secundário }\end{array}$ & $\begin{array}{l}\text { 1918, 194-. } 12 \text { a } 15 \text { ed.; } \\
\text { 193-, 19. Ed., 194-, 17. ed. }\end{array}$ & LIVRES \\
\hline & $\begin{array}{l}\text { História do Brasil: para o } \\
\text { ensino elementar (ginásio) }\end{array}$ & 1943, 22. ed. & LIVRES \\
\hline & História do Brasil: curso & 1941 4.ed. Melhoramentos & LIVRES \\
\hline
\end{tabular}

\footnotetext{
${ }^{26}$ José Maria da Silva Paranhos, o Barão do Rio Branco, escreveu em francês a História do Brasil a convite de Levasseur para definir o verbete "Brésil" da Grande Enciclopédia durante sua estada em Liverpool (1876-1893). O livro publicado no Brasil em 1894, pela Livraria Teixeira e Irmão. Em 1930 é publicada por José Bernardino Paranhos da Silva, sobrinho do Rio Branco, em colaboração com Max Fleiuss. Bernardino Paranhos atualizou o texto incluindo um resumo da história da República até 1930. Em 1948 o Itamarati publicou o texto original em francês. E em 1958 o texto acrescido de notas do autor localizado n Biblioteca Nacional, o chamado "exemplar Nabuco", foi publicado pelo Instituto Rio Branco com prefácio de José Honório Rodrigues. Em 1964 é reeditado pelo governo de São Paulo. Cf. Gomes (1999, p. 106 e 113).
} 


\begin{tabular}{|c|c|c|c|}
\hline & fundamental (secundário) & & \\
\hline Lindolpho POMBO & $\begin{array}{c}\text { Brasil nas Escolas: leituras } \\
\text { progressivas }\end{array}$ & $\begin{array}{l}\text { 1912, 4. ed., Livraria } \\
\text { Magalhães. }\end{array}$ & LIVRES \\
\hline $\begin{array}{l}\text { Luiz de Queirós } \\
\text { Mattoso MAIA }\end{array}$ & Lições de História do Brasil & $\begin{array}{l}1898 \\
1908 \text { 6. ed., Tip. Americano }\end{array}$ & $\begin{array}{c}\text { LIVRES } \\
\text { Moreira e } \\
\text { Silva (2011) } \\
\text { Vechia e } \\
\text { Lorenx (1998) }\end{array}$ \\
\hline Luiz PINTO & História do Povo Brasileiro & $\begin{array}{l}\text { 1948, RJ: A. Coelho Branco } \\
\text { Filho Editor }\end{array}$ & $\begin{array}{c}\text { Moreira e } \\
\text { Silva (2011) }\end{array}$ \\
\hline Maria de BARROS & História do Brasil & 1932, SP: Liberdade & $\begin{array}{l}\text { Moreira e } \\
\text { Silva (2011) }\end{array}$ \\
\hline $\begin{array}{l}\text { Mário da Veiga } \\
\text { CABRAL }\end{array}$ & $\begin{array}{c}\text { Compendio de História do } \\
\text { Brasil }\end{array}$ & $\begin{array}{c}1920 \\
\text { 1923, 3. ed. Jacinto Ribeiro } \\
\text { dos Santos, } \\
1926\end{array}$ & $\begin{array}{c}\text { Moreira e } \\
\text { Silva (2011) } \\
\text { LIVRES } \\
\text { Vechia e } \\
\text { Lorenx (1998) }\end{array}$ \\
\hline \multirow[b]{2}{*}{ Mário SETTE } & $\begin{array}{l}\text { História do Brasil: terceira } \\
\text { série do curso ginasial }\end{array}$ & 1946 2. ed. & $\begin{array}{l}\text { Moreira e } \\
\text { Silva (2011) } \\
\text { LIVRES }\end{array}$ \\
\hline & $\begin{array}{l}\text { História do Brasil: quarta série } \\
\text { do curso ginasial }\end{array}$ & 1947 2.ed. Melhoramentos & $\begin{array}{c}\text { Moreira e } \\
\text { Silva (2011) } \\
\text { Holanda } \\
(1957) \\
\end{array}$ \\
\hline Max FLEIUSS & $\begin{array}{c}\text { Apostilas de História do Brasil } \\
\text { (curso ginasial) }\end{array}$ & $\begin{array}{l}\text { 1933, 1. ed.; 1940, 3. ed., } \\
\text { Libraria do Globo }\end{array}$ & $\begin{array}{l}\text { Moreira e } \\
\text { Silva (2011) }\end{array}$ \\
\hline Menezes VIEIRA & Nossa história pátria & 1891, Francisco Alves & $\begin{array}{l}\text { Moreira e } \\
\text { Silva (2011) }\end{array}$ \\
\hline $\begin{array}{c}\text { Othello de Sousa } \\
\text { REIS }\end{array}$ & História do Brasil & $\begin{array}{l}\text { 1930, 4. ed., Francisco } \\
\text { Alves }\end{array}$ & $\begin{array}{c}\text { Vechia e } \\
\text { Lorenx (1998) } \\
\end{array}$ \\
\hline \multirow{2}{*}{ Orestes ROSALIA } & História do Brasil. $3^{\mathrm{a}}$ série. & Francisco Alves, 1948, 2. ed & $\begin{array}{l}\text { Holanda } \\
(1957)\end{array}$ \\
\hline & História do Brasil. $4^{\mathrm{a}}$ série & Francisco Alves, 1944. & $\begin{array}{l}\text { Holanda } \\
\text { (1957) }\end{array}$ \\
\hline \multirow{3}{*}{$\begin{array}{l}\text { Osório DUQUE- } \\
\text { ESTRADA }\end{array}$} & História do Brasil & $\begin{array}{c}\text { 1918, 1922, 3. ed., Jacinto } \\
\text { Ribeiro dos Santos, } 19276 . \\
\text { ed. RJ: Francisco Alves }\end{array}$ & LIVRES \\
\hline & $\begin{array}{l}\text { História do Brasil para uso das } \\
\text { escolas normais e liceus }\end{array}$ & $\begin{array}{c}\text { 1922, RJ: Joaquim Ribeiro } \\
\text { dos Santos }\end{array}$ & $\begin{array}{c}\text { Moreira e } \\
\text { Silva (2011) }\end{array}$ \\
\hline & Noções de História do Brasil & $\begin{array}{l}\text { 1927, 6. ed.; 1930, 7. ed.; } \\
\text { Francisco Alves } \\
\text { 1933, 8. ed. Francisco Alves }\end{array}$ & LIVRES \\
\hline Pedro do COUTTO & "Pontos de História do Brasil" & $\begin{array}{c}\text { 1918, 1920. 1923, 3. ed., } \\
\text { Jacinto Ribeiro dos Santos } \\
\text { Editor, }\end{array}$ & $\begin{array}{c}\text { Moreira e } \\
\text { Silva (2011) } \\
\text { LIVRES } \\
\text { Vechia e } \\
\text { Lorenz (1998) }\end{array}$ \\
\hline \multirow{2}{*}{$\begin{array}{l}\text { Rafael Maria de } \\
\text { GALANTI }\end{array}$} & $\begin{array}{c}\text { Compêndio de História do } \\
\text { Brasil }\end{array}$ & 1902 e 1910, Duprat & LIVRES \\
\hline & História do Brasil & 1911, 2.ed., Duprat & $\begin{array}{l}\text { Moreira e } \\
\text { Silva (2011) } \\
\text { LIVRES }\end{array}$ \\
\hline
\end{tabular}




\begin{tabular}{|c|c|c|c|}
\hline & História do Brasil: tomo II & 1911, Duprat & LIVRES \\
\hline & História do Brasil: tomo IV & 1913, Duprat & LIVRES \\
\hline & Licções de História do Brasil & $\begin{array}{l}18952 \text {. ed., } 18964 \text { 4. ed., } \\
\text { 1913, 5. ed., Duprat }\end{array}$ & $\begin{array}{c}\text { LIVRES } \\
\text { Moreira e } \\
\text { Silva (2011) } \\
\end{array}$ \\
\hline \multirow[t]{2}{*}{ Raul VILLA-LOBOS } & Pontos de História do Brasil & $\begin{array}{c}\text { Rio de Janeiro, 1886; } \\
\text { 1889, 2. ed. Laemmert \& C. } \\
\text { Editores, } 1891 \text { 3. ed., Cia. } \\
\text { Tip. do Brasil } \\
1895\end{array}$ & LIVRES \\
\hline & $\begin{array}{c}\text { História do Brasil: resumo } \\
\text { didático }\end{array}$ & $\begin{array}{l}\text { 1891, 3. ed., Cia Tip. do } \\
\text { Brasil; 1896, 4. ed., Tip. } \\
\text { Universal Laemmert }\end{array}$ & LIVRES \\
\hline $\begin{array}{c}\text { Renato Firmino Maria } \\
\text { de MENDONÇA }\end{array}$ & Pequena História do Brasil & $\begin{array}{l}\text { 1946: Lisboa: Grafica } \\
\text { Limitada }\end{array}$ & $\begin{array}{c}\text { Moreira e } \\
\text { Silva (2011) }\end{array}$ \\
\hline \multirow{2}{*}{$\begin{array}{l}\text { Sergio Buarque de } \\
\text { HOLLANDA \& } \\
\text { Otávio Tarquínio de } \\
\text { SOUZA }\end{array}$} & História do Brasil & $\begin{array}{l}\text { 1944, Ed. Livraria José } \\
\text { Olympio }\end{array}$ & $\begin{array}{c}\text { Moreira e } \\
\text { Silva (2011) }\end{array}$ \\
\hline & História do Brasil ( $3^{\mathrm{a}}$ série) & José Olimpio, 1944. & $\begin{array}{l}\text { Holanda } \\
\text { (1957) }\end{array}$ \\
\hline Silvio ROMERO & $\begin{array}{l}\text { A história do Brasil ensinada } \\
\text { pela biografia de seus heróis }\end{array}$ & 1890, Clássica de Alves & $\begin{array}{c}\text { Moreira e } \\
\text { Silva (2011) }\end{array}$ \\
\hline Tabajara PEDROSO & $\begin{array}{l}\text { História do Brasil: destinada às } \\
3^{a} \text { e } 4^{a} \text { séries do curso ginasial }\end{array}$ & 1946 & LIVRES \\
\hline $\begin{array}{l}\text { Tito Lívio } \\
\text { FERREIRA }\end{array}$ & $\begin{array}{l}\text { História do Brasil: pra terceira } \\
\text { e quarta séries ginasiais }\end{array}$ & $\begin{array}{l}\text { 1946, 3. ed. Editora } \\
\text { Nacional } \\
\text { 1947 4.ed. }\end{array}$ & $\begin{array}{c}\text { Moreira e } \\
\text { Silva (2011) } \\
\text { LIVRES }\end{array}$ \\
\hline \multirow{3}{*}{ Vicente TAPAJÓS } & \multirow[b]{2}{*}{$\begin{array}{l}\text { História do Brasil adaptada ao } \\
\text { Curso de Colégio }\end{array}$} & $\begin{array}{l}1944 \text { 1. ed. Editora } \\
\text { Nacional }\end{array}$ & $\begin{array}{l}\text { Holanda } \\
\text { (1957) }\end{array}$ \\
\hline & & $\begin{array}{c}1946 \text { 2.ed. } \\
1954 \text { 6.ed. } \\
1965 \text { 12. ed. Editora } \\
\text { Nacional } \\
1967 \text { 14.ed. } \\
1969 \text { 15.ed. } \\
\end{array}$ & $\begin{array}{l}\text { Moreira e } \\
\text { Silva (2011) } \\
\text { LIVRES }\end{array}$ \\
\hline & $\begin{array}{c}\text { Manual de História do Brasil } \\
\left(I^{a} \text { série ginasial }\right)\end{array}$ & 1955 1. Ed. & $\begin{array}{c}\text { Moreira e } \\
\text { Silva (2011) }\end{array}$ \\
\hline Viriato CORREA & Contos da História do Brasil & $\begin{array}{l}\text { 1921, Livraria Castilho, Tip. } \\
\text { do Anuário do Brasil, } \\
\text { Almanak Laemmert. }\end{array}$ & LIVRES \\
\hline
\end{tabular}

Recebido: 12/03/2017

Aprovado: 20/04/2017 